\title{
Effect of length of LOCATOR abutment and cement type on retention to intraradicular dentin in overdentures
}

\author{
Aleisa, Khalil ; Al-Dwairi, Ziad ; Abou-Obaid, Alaa ; Al-Muharib, Aseel ; Al-Rejaye, Najla ; Morgano,
} Steven M ; Al-Haj Husain, Nadin ; Özcan, Mutlu

\begin{abstract}
STATEMENT OF PROBLEM Limited information is available on the effect of LOCATOR abutment length and luting cement type on retention to intraradicular dentin in overdentures. PURPOSE The purpose of this in vitro study was to evaluate the effect of the length of a commercially available LOCATOR abutment and cement type on retention in the root canal. MATERIAL AND METHODS Eighty LOCATOR abutments with a standard length of $6 \mathrm{~mm}$ were obtained. Half of them were shortened to $3 \mathrm{~mm}$. Eighty recently extracted single-rooted teeth were divided into 2 groups. The post space was prepared to $6 \mathrm{~mm}$ in the first group and $3 \mathrm{~mm}$ in the second. After preparation, the LOCATOR abutments were luted with one of the following cements: dual-polymerized glass-reinforced resin cement (Parapost Paracore), dual-polymerized resin cement (Variolink II), self-adhesive resin cement (RelyX Unicem), and conventional cement (zinc phosphate). The tensile force required for the removal of the LOCATOR abutments from their corresponding roots was recorded. Data were statistically analyzed with 2-way ANOVA and the Tukey multiple comparison test. RESULTS Both the cement type $(\mathrm{P}<.001)$ and the length of the LOCATOR abutment $(\mathrm{P}<.001)$ significantly affected the mean tensile forces. Dualpolymerized glass-reinforced resin cement (Parapost Paracore) presented significantly higher mean tensile forces for the LOCATOR abutment retention among all cements $(\mathrm{P}<.05)$. CONCLUSIONS Regardless of the length, LOCATOR abutments luted with Parapost Paracore resin cement presented higher mean resistance to tensile forces compared with those luted with the other cements. LOCATOR abutments of $6 \mathrm{~mm}$ in length were more resistant to tensile forces than those of $3 \mathrm{~mm}$ in length in combination with all cements.
\end{abstract}

DOI: https://doi.org/10.1016/j.prosdent.2019.04.023

Posted at the Zurich Open Repository and Archive, University of Zurich ZORA URL: https://doi.org/10.5167/uzh-184098

Journal Article

Accepted Version

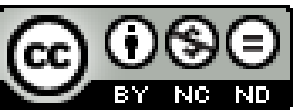

The following work is licensed under a Creative Commons: Attribution-NonCommercial-NoDerivatives 4.0 International (CC BY-NC-ND 4.0) License.

Originally published at:

Aleisa, Khalil; Al-Dwairi, Ziad; Abou-Obaid, Alaa; Al-Muharib, Aseel; Al-Rejaye, Najla; Morgano, Steven M; Al-Haj Husain, Nadin; Özcan, Mutlu (2019). Effect of length of LOCATOR abutment and 
cement type on retention to intraradicular dentin in overdentures. Journal of Prosthetic Dentistry, 122(2):152.e1-152.e6.

DOI: https://doi.org/10.1016/j.prosdent.2019.04.023 
Effect of length of Locator abutment and cement type on the retention to intraradicular dentin in overdentures

Khalil Aleisa; BDS, MSc,* Alaa Abou-Obaid; BDS,** Aseel Al-Muharib; BDS,*** Najla AlRejaye; BDS, **** Ziad AL-Dwairi; BDS, PhD , FIADFE, FICD, FADI,\# Steven m. Morgano, DMD,\#\#

\section{Original Article}

Running title: Vertical Displacement of Locator posts cemented with resin cement

* Professor, Department of Prosthetic Dental Sciences, College of Dentistry, King Saud University, Riyadh, Saudi Arabia

** Demonstrator, Department of Prosthetic Dental Sciences, College of Dentistry, King Saud University.

*** General Practitioner, Dental Department, King Abdulaziz Medical City, Riyadh, Saudi Arabia **** General Practitioner, Dental Department, King Abdulaziz Medical City, Riyadh, Saudi Arabia

\# Professor, Department of Prosthodontics, Faculty of Dentistry, Jordan University of Science and Technology, Irbid-Jordan

\#\# Professor of Restorative Sciences and Biomaterials, Director, Division of Postdoctoral Prosthodontics, Boston University, Henry M. Goldman School of Dental Medicine, USA 
Corresponding author:

Ziad N. AL-Dwairi

Professor of Prosthodontics

Department of Prosthodontics

Faculty of Dentistry

Jordan University of Science and Technology

Po Box 3030, Irbid 22110-Jordan

Email : ziadd@just.edu.jo

Key words: Overdentures; Locator attachment; Resin Cement

Number of pages: 21

Number of Figures: 1

Numbers of Tables: 3

Reprint: 0 


\begin{abstract}
Statement of problem. Limited information is available on the effect of Locator abutment length and luting cement type on the retention to intraradicular dentin in overdentures.
\end{abstract}

Purpose. The purpose of this in vitro study was to evaluate the effect of a commercially available Locator abutment length and cement type on the retention in the root canal.

Material and methods. Eighty Locator abutments with a standard length of $6 \mathrm{~mm}$ were obtained. Half of them were shortened to $3 \mathrm{~mm}$. Eighty recently extracted single-rooted teeth were divided into 2 groups. The post space was prepared to $6 \mathrm{~mm}$ in the first group and $3 \mathrm{~mm}$ in the second. After preparation, Locator abutments were luted with one of the following cements: dual-polymerized glass-reinforced resin cement (Parapost Paracore), dual-polymerized resin cement (Variolink II), self-adhesive resin cement (RelyX Unicem) and conventional cement (zinc phosphate). The tensile force required for the removal of the Locator abutments from their corresponding roots were recorded. Data were statistically analyzed with 2-way ANOVA and the Tukey multiple comparison test.

Results. Both the cement type $(P<.001)$ and the length of the Locator abutment $(P<.001)$ significantly affected the mean tensile forces. Dual-polymerized glass-reinforced resin cement (Parapost Paracore) presented significantly higher mean tensile forces for the Locator abutment retention among all cements $(P<.05)$.

Conclusions. Regardless of the length, Locator abutments luted with Parapost Paracore resin cement presented higher mean resistance to tensile forces compared with those luted with the other cements. Locator abutments of $6 \mathrm{~mm}$ length were more resistant to tensile forces than those of $3 \mathrm{~mm}$ length in combination with all cements 


\section{CLINICAL IMPLICATIONS}

Retention of Locator abutments to root dentin in overdenture indications increased with the increase of the length from 3 to $6 \mathrm{~mm}$ with the cement types tested, except for the Parapost Paracore resin cement tested with which length did not affect the results and therefore could be indicated for shorter Locator abutments.

\section{INTRODUCTION}

A complete removable overdenture (CRO) is a prosthesis that is supported by the residual alveolar ridge along with the remaining teeth or oral implants.1 Improved retention and stability can be provided with the use of attachments.2

Several types of attachments are available to provide retention between the Locator abutment and a CRO. A common approach is the use of a intraradicular Locator abutment (Locator Root Attachment; Zest Anchors Inc.), where a supra-radicular design is used and Locator abutment is cemented to the retentive insert. The retentive insert is composed of the abutment and its post, which is made of titanium with a titanium-nitride coating. The Locator abutment is cemented to intraradicular dentin after root canal preparation with specially designed drills. The Locator abutment is a cap with an interchangeable retentive component that engages with the retentive insert to stabilize and increase retention of the CRO under tensile forces.

Clinically, the Locator abutment is embedded in the CRO while the retentive insert remains intraorallyз where Locator abutment length, design, and cement type may affect their retention.4-8 Typically, longer Locator abutments are more retentive and produce less stress to the intraradicular dentin.4,5,9,10 
Johnson and Sakumuras measured the tensile forces required to remove endodontic posts from extracted maxillary lateral incisors and reported that retention increased by $30 \%$ when the post length increased from 7 to $11 \mathrm{~mm}$. Similarly, Borer et al11 studied the effect of post length on the retention of 2 different prefabricated posts and reported that posts with a length of $10 \mathrm{~mm}$ were significantly more retentive than those with $5 \mathrm{~mm}$. However, the use of shorter posts may result in post loosening or root fracture.9,12,13 While Borer et al11 reported that posts shorter than half of the root length would not yielded to root fracture, Nissan et al14 suggested the use of reinforced composite resin cement to compensate for reduced post length. They also reported no significant differences between the mean retention force needed for the posts luted with FlexiFlow composite resin cement for 5, 8, and $10 \mathrm{~mm}$ post lengths used in their study. 1 Commercially available overdenture Locator abutments are provided at a length of $6 \mathrm{~mm}$, although it was reported by Pavlatos 3 that these posts can be shortened to $3 \mathrm{~mm}$ in length. In some clinical situations, shorter Locator abutments may be required due to unfavorable root anatomy or the necessity of preserving a 5-mm apical gutta percha seal in the presence of bone loss. In that respect, the choice of the cement can be critical.5,6-8,15,16

Several types of luting agents have been suggested for the cementation of posts including zinc phosphate, glass ionomer, resin, and resin-modified glass-ionomer cements.6,7,14,17-20 While some studies reported similar or improved retention with traditional cements when compared with resin cements,19,20 others found contradictory results.6,14,17 Among conventional cements, retention of cast posts-and-cores were significantly higher with zinc phosphate than that of glass ionomer cement 24 hours after cementation. 7

Although Locator abutments for overdenture posts are provided at a length of $6 \mathrm{~mm}$, and it has been suggested that they can be shortened to as little as $3 \mathrm{~mm}$ in length,3 to the best of the 
authors' knowledge, no study to date evaluated the effect of Locator abutment length and cement type on their retention to intraradicular dentin.

The objectives of this study were to evaluate the effects of locator abutment lengths and cement types on their retention to the intraradicular dentin in overdentures. The null hypothesis tested was that length and cement parameters would not affect the retention of Locator abutments.

\section{MATERIAL AND METHODS}

This study was approved by the Board Council and Research Center of the College of Dentistry, King Saud University (grant no. F1184). Eighty recently extracted human permanent singlerooted teeth were sectioned horizontally $1 \mathrm{~mm}$ incisal to the mid-facial cemento-enamel junction with a straight fissure carbide bur (KE-FG057 5-PK; Komet) using a high-speed handpiece under copious water coolant, leaving a flat coronal surface. The root canals were not endodontically treated.

The teeth were randomly divided into 2 groups of 40 each. The retentive post space was prepared to a depth of either 3 or $6 \mathrm{~mm}$. The post space was prepared initially with reamers (Peeso; Pulpdent Corp.), then with the pilot drill provided by the manufacturer of the Locator abutment (MODEL: \#8924; Zest Anchor Inc.) and finally with the countersink diamond rotary instrument (Zest Anchors Inc.) mounted in a conventional slow-speed handpiece under copious water coolant.

The root of the teeth were roughened with an inverted cone carbide bur (\#H2-012 Inverted Cone; Komet) and a hole was prepared $3 \mathrm{~mm}$ coronal to the apex using a quarter round carbide bur (Komet). An orthodontic wire (Remanium spring hard wire; Dentaurum Inc.) of 0.5 
$\mathrm{mm}$ in diameter was inserted into the hole and twisted to a length of $10 \mathrm{~mm}$. The roots were then mounted in auto-polymerized acrylic resin (Ortho Resin, Dentsply DeTrey) in a poly (vinyl chloride) cylinder. A dental surveyor (J.M. Ney Co., Bloomfield, Conn) was used to position the roots parallel in the acrylic resin.

Eighty Locator abutments (LOCATOR Root Attachment System; Zest Anchors Inc.) of 6 $\mathrm{mm}$ length were obtained and half of them were shortened to $3 \mathrm{~mm}$ using diamond discs (Chrome Cobalt cut-off disks; Jelenko Inc.) using a slow-speed handpiece.

The Locator abutments in each group were randomly assigned to 4 subgroups $(n=10)$, according to the cement type. Root canals were irrigated with $0.5 \%$ sodium hypochlorite and saline and then dried with absorbent paper points (Sure-endo; Sure Dent Corp.). After ensuring that Locator abutments fit passively when completely seated in their respective canals, they were then luted with one of 4 different luting agents (Table 1):

Dual-polymerized glass-reinforced resin composite cement: Root dentin was conditioned with the non-rinse conditioner (ParaBond Non-Rinse Conditioner; Coltene Whaledent) for 30 seconds, and adhesive resin (ParaBond Adhesive A/B; Coltene Whaledent) was applied for 30 seconds. Locator abutments were then cemented using dual-polymerized glass-reinforced resin composite cement (ParaPost Paracore; Coltene Whaledent) where the cement was applied directly from the tip of the syringe into the root. The Locator abutments were also coated with the cement and then inserted in the canal with slight pressure using the insertion key of the attachment kit (Zest order \#9201; Zest Anchors Inc.). Excess cement was removed, and photopolymerization (XL 2500, 3M ESPE) was performed for 40 seconds.

Dual-polymerized resin cement: In this group, root dentin was acid etched with $37 \%$ phosphoric acid gel 37\% (Ivoclar Vivadent; Ivoclar Vivadent) for 15 seconds. The adhesive resin 
(Excite DSC; Ivoclar Vivadent) was applied to the canal with a microbrush, and excess adhesive was removed with (Ultradent's Paper Points; Ultradent). The Locator abutments were luted using dual-polymerized resin cement (Variolink II; Ivoclar Vivadent). The cement was mixed 1:1 on a mixing pad for 10 seconds and applied to the root canal with a lentulo spiral (Lentulo Spiral 25/1; Dentsply Maillefer). The Locator abutments were coated with the cement and inserted in the prepared intraradicular canal. Excess cement was removed, and photo-polymerization was performed as described above.

Dual-polymerized self-adhesive resin cement: In this group, Locator abutments were luted using a dual-polymerized self-adhesive resin cement (RelyX Unicem; 3M ESPE) where the cement capsule was activated for 2 seconds and mixed automatically in a high-speed triturator for 10 seconds. The Locator abutments were coated with the cement and the resin cement was applied in the intraradicular canal (Elongation Tip; 3M ESPE). Excess cement was removed, and photo-polymerization was performed as previously described.

Conventional cement: Zinc phosphate cement (Kleio; Lascod SpA) was mixed on a thick, cold glass slab. The powder was divided into multiple portions and introduced into the liquid in increments. The cement was introduced in the root canal with a lentulo spiral (Paste filler; Kerr/Sybron Corp.) rotating in slow-speed handpiece. The Locator abutments were coated with the cement and inserted into the prepared canal. The cement was allowed to set, and then excess cement was removed.

Specimens were stored at $100 \%$ relative humidity at $37^{\circ} \mathrm{C}$ for 24 hours before testing. Subsequently, each specimen was vertically secured in the universal testing machine (Instron, Model 8500 Plus Dynamic Testing System; Instron Corp.). A customized self-aligning testing assembly was used which included a U-shaped stainless steel rod with an opening at each end as 
well as a horizontal rod that passed through a channel prepared through the lower part of the acrylic resin block, along with the openings of the U-shaped rod (Fig. 1). The hook of the lower part of the testing machine held the curved portion of the U-shaped rod and the extended part of the cemented Locator abutment was clamped using a customized fixation attached to the upper part of the universal testing machine (Fig. 1). Tensile force was applied with load cell of 5KN at a crosshead speed of $0.5 \mathrm{~mm} / \mathrm{min}$. Each specimen was tested to failure, and the forces required for the dislodgment of the Locator abutments were recorded in Newtons $(\mathrm{N})$.

Statistical analyses of the data were performed using a 2-way analysis of variance (ANOVA) and Tukey test where the tensile force was the dependent variable and the length (2 levels) cement types (4 levels) were independent variables (SPSS v.16.0; SPSS Corp.). $P$ values less than .05 were considered to be statistically significant in all tests.

\section{RESULTS}

Both the cement type $(P<.0001)$ and the length of the locator abutment $(P<.0001)$ significantly affected the mean tensile forces (Table 2). Interaction terms were not significant $(P>.05)$. Regardless of the locator abutment length, the use of Parapost Paracore cement for luting abutments to radicular dentin presented significantly higher results compared to those of other cements $(P<.0001)$, except for the $6 \mathrm{~mm}$ locator abutments luted with Variolink II $(P>.05)$ (Table 3).

Within the $3 \mathrm{~mm}$ groups, the Parapost Paracore resin cement showed significantly the highest retention compared to other dual-polymerized resin, self-adhesive resin and zinc phosphate cement groups $(P<.05)$ (Fig. 2). 


\section{DISCUSSION}

This study aimed to investigate the effect of two lengths and 4 cement types on the retention of Locator abutments to intraradicular dentin in overdenture. Since length and cement types significantly affected the mean retention values, the null hypothesis was rejected.

In this study, in order to eliminate possible confounding factors, the root canals were not obturated with endodontic sealers. However, such sealers could decrease the post retention.18,21 Tensile force was used in this study to determine the values required to remove the Locator abutments from the intraradicular canal in overdenture since the type of force generated during denture removal involves tensile forces along the long axis of the locator. In addition, pull-out retention tests have been widely accepted and used in most studies that have evaluated retentive values of cemented endodontic posts.5-7,14,19,20-21

A search of the literature published over the last decade revealed no studies addressing the effects of the length of Locator abutments and cement types on their retention. Therefore, the most reasonable comparisons that can be made with previous studies relate to studies that investigated different endodontic metal posts. The results of the present study indicated that Locator abutment length had a significant effect on retention. Locators that were $6 \mathrm{~mm}$ in length exhibited higher retention values than those in $3 \mathrm{~mm}$ in length, regardless of the type of cement. This finding is consistent with previous studies of metal posts $4,5,11$ and also indicates that retention increases in proportion with length and surface area.

In the present study, retentive forces of the $3 \mathrm{~mm}$ Locator abutments can be compared with the results reported by Sahafi et al.,22 where they recorded $238 \mathrm{~N}$ for ParaPost resin cement and $180 \mathrm{~N}$ for zinc phosphate cement when $3 \mathrm{~mm}$ parallel titanium ParaPost XH posts were 
used. The reasons for the differences with the present study could be related to the surface treatment of the posts.22

Forces required to dislodge locator abutments luted with Parapost Paracore resin cement were significantly higher than forces associated with the other cements 24 hours after cementation. A possible reason for this finding is the optimal monoblock bonded interface between the Locater abutment, cement and dentin, resulting in one cohesive mass.23 Unlike traditional cements, adhesive resin cement systems may provide a micromechanical and chemical bond to the dentin and to the post itself.15,19,24 Parapost Paracore and Variolink II resin cements exhibited significantly higher retention than those with the self-adhesive universal resin cement (RelyX Unicem). Also, Locator abutments luted with zinc phosphate cement recorded significantly higher retention compared to those cemented with the self-adhesive universal resin cement. This result is in disagreement with the findings reported by Balbosh et al 19 where the retention recorded for titanium posts luted with the self-adhesive universal resin cement (RelyX Unicem) was not significantly different when compared with retention values obtained with zinc phosphate cement. However, when the intraradicular dentin was roughened with a diamond rotary instrument, retention values were statistically higher for the self-adhesive resin cement.19 In the present study, large standard deviations were recorded similar to previous studies.6,7,21,22 The reason for this may be related to the complex physical and biological properties intraradicular dentin. It was previously suggested that Locator abutments may be shortened up to $3 \mathrm{~mm}$ in length.3 The results of this study partly support this assumption provided that the $3 \mathrm{~mm}$ Locators were luted with a strong adhesive resin cement. It is interesting to note that the results of the present study indicated that the retention of $3 \mathrm{~mm}$ Locators luted with Parapost Paracore resin cement was comparable to the retention of the $6 \mathrm{~mm}$ ones luted 
with the other cements. Intraoral stresses from removable dentures are much less than those from natural teeth.25,26 Furthermore, the type of force on the intraradicular attachments during denture removal is primarily a tensile force along the long axis of the tooth, unlike forces associated with fixed prostheses luted to natural teeth. Intraoral forces on overdenture attachments are complex because the load acting on Locator abutments can be much higher for shorter abutments with occlusal forces producing a leverage effect that potentially could lead to its loosening. Therefore, long-term clinical studies are recommended to verify the clinical success of $3 \mathrm{~mm}$ Locator abutments in overdenture.

In this study, thermocycling and dynamic loading were not conducted and therefore the results represent early clinical failures. In-vitro artificial aging could have altered the results. Also, endodontic treatment was not performed on the extracted teeth prior to luting the Locator abutments which could be considered as a limitation of this study. Future studies should include parameters of ferrule and the use of endodontic sealer.

\section{CONCLUSIONS}

From this study, the following conclusions were drawn:

1. Locator abutments of $6 \mathrm{~mm}$ length in overdentures were more resistant to tensile forces than those of $3 \mathrm{~mm}$ length in combination with both resin-based and conventional cement types tested 24 hours after luting.

2. Within the $3 \mathrm{~mm}$ groups, dual-polymerized Parapost Paracore resin cement showed significantly higher mean retention values compared to other dual-polymerized resin, self-adhesive resin and zinc phosphate cement groups. 
3. Mean retention values for Locator abutments of $6 \mathrm{~mm}$ length were similar when cemented with dual-polymerized resin cements (Parapost Paracore and Variolink II) being significantly higher than those luted with self-adhesive resin or zinc phosphate cement. 


\section{REFERENCES}

1. Mericske-Stern R. Overdentures with roots or implants for elderly patients: A comparison. J Prosthet Dent 1994;72:543-50.

2. Mensor M. Attachment fixation for overdentures: Part I. J Prosthet Dent 1977;37:366-73.

3. Pavlatos J. The root-supported overdentures using the locator overdenture attachment. Gen Dent 2002;50:448-53.

4. Johnson JK, Sakumura JS. Dowel form and tensile force. J Prosthet Dent 1978;40:645-9.

5. Standlee JP, Caputo AA, Hanson EC. Retention of endodontic dowel: effects of cement, dowel length, diameter, and design. J Prosthet Dent 1978;39:400-5.

6. Duncan JP, Pameijer CH. Retention of parallel-sided titanium posts cemented with six luting agents: an in vitro study. J Prosthet Dent 1998;80:423-8.

7. Al Wazzan K, Al Ali K. Retention of cast post and core cemented with three luting agents. Egypt Dent J 2005;52:1333-9.

8. Peroz I, Blankenstein F, Lange KP, Naumann M. Restoring endodontically treated teeth with posts and cores: A review. Quintessence Int 2005;36:737-46.

9. Standlee JP, Caputo AA, Collard EW, Pollack MH. Analysis of stress distribution by endodontic posts. Oral Surg Oral Med Oral Pathol 1972;33:952-60.

10. Holmes DC, Diaz-Arnold AM, Leary JM. Influence of post dimension on stress distribution in dentin. J Prosthet Dent 1996;72:140-7.11. Borer RE, Britto LR, Haddix JE. Effect of dowel length on the retention of 2 different prefabricated posts. Quintessence Int 2007;38:164-8.

12. Ross IF. Fracture susceptibility of endodontically treated teeth. J Endod 1980;6:560-5. 13. Morgano SM, Milot P. Clinical success of cast metal post and cores. J Prosthet Dent 1993;70:11-6. 
14. Nissan J, Dmitry Y, Assif D. The use of reinforced composite resin cement as compensation for reduced post length. J Prosthet Dent 2001;86:304-8.

15. Utter JD, Wong BH, Miller BH. The effect of cementing procedures on retention of prefabricated metal posts. J Am Dent Assoc 1997;128:1123-7.

16. Cohen BI, Deutsh AS, Musikant BL. Cyclic fatigue testing of six endodontic post systems. J Prosthodont 1993;2:28-32.

17. Chan FW, Harcourt JK, Brockhurst PJ. The effect of post adaptation in the root canal on retention of posts cemented with various cements. Aust Dent J 1993;38:39-45.

18. Hagge MS, Wong RD, Lindemuth JS. Retention strengths of five luting cements on prefabricated dowels after root canal obturation with a zinc oxide/eugenol sealer: 1. Dowel space preparation/ cementation at one week after obturation. J Prosthodont 2002;11:168-75.

19. Balbosh A, Ludwig K, Kern M. Comparison of titanium dowel retention using four different luting agents. J Prosthet Dent 2005;94:227-33.

20. Habib B, von Fraunhofer JA, Driscoll CF. Comparison of two luting agents used for the retention of cast dowel and cores. J Prosthodont 2005;14:164-9.

21. Aleisa K, Alghabban R, Alwazzan K, Morgano SM. Effect three endodontic sealers on the bond strength of prefabricated fiber posts luted with three resin cements. J Prosthet Dent 2012;107:322-6.

22. Sahafi A, Peutzfeldt A, Asmussen E, Gotfredsen K. Retention and failure morphology of prefabricated posts. Int J Prosthodont 2004;17:307-12.

23. Melo Freire CA, Borges GA, Caldas D, Santos RS. marginal adaptation and quality of interfaces in lithium disilicate crowns - influence of manufacturing and cementation techniques. Oper Dent 2017;42:185-95. 
24. Mendoza DB, Eakle WS, Kahl EA, Ho R. Root reinforcement with a resin-bonded preformed post. J Prosthet Dent 1997;78:10-4.

25. Pacer RJ, Bowman DC. Occlusal force discrimination by denture patients. J Prosthet Dent 1975;33:602-9.

26. Rissin L, House JE, Manly RS, Kapur KK. Clinical comparison of masticatory performance and electromyographic activity of patients with complete dentures, overdentures and natural teeth. J Prosthet Dent 1978;39:508-11. 


\section{FIGURES}

Fig. 1 Specimen in customized self-aligning testing assembly mounted in universal testing machine.

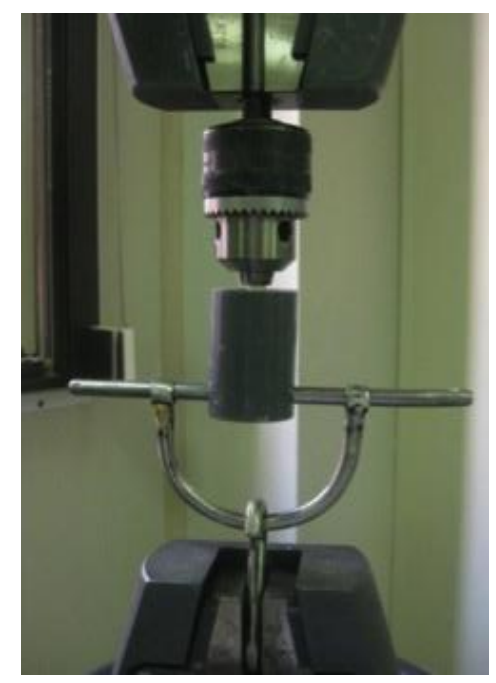

Fig. 2 Boxplot presentation with inter-quartile range and medians of retention results $(\mathrm{N})$ of Locator abutments in overdentures as a function of length and cement types.

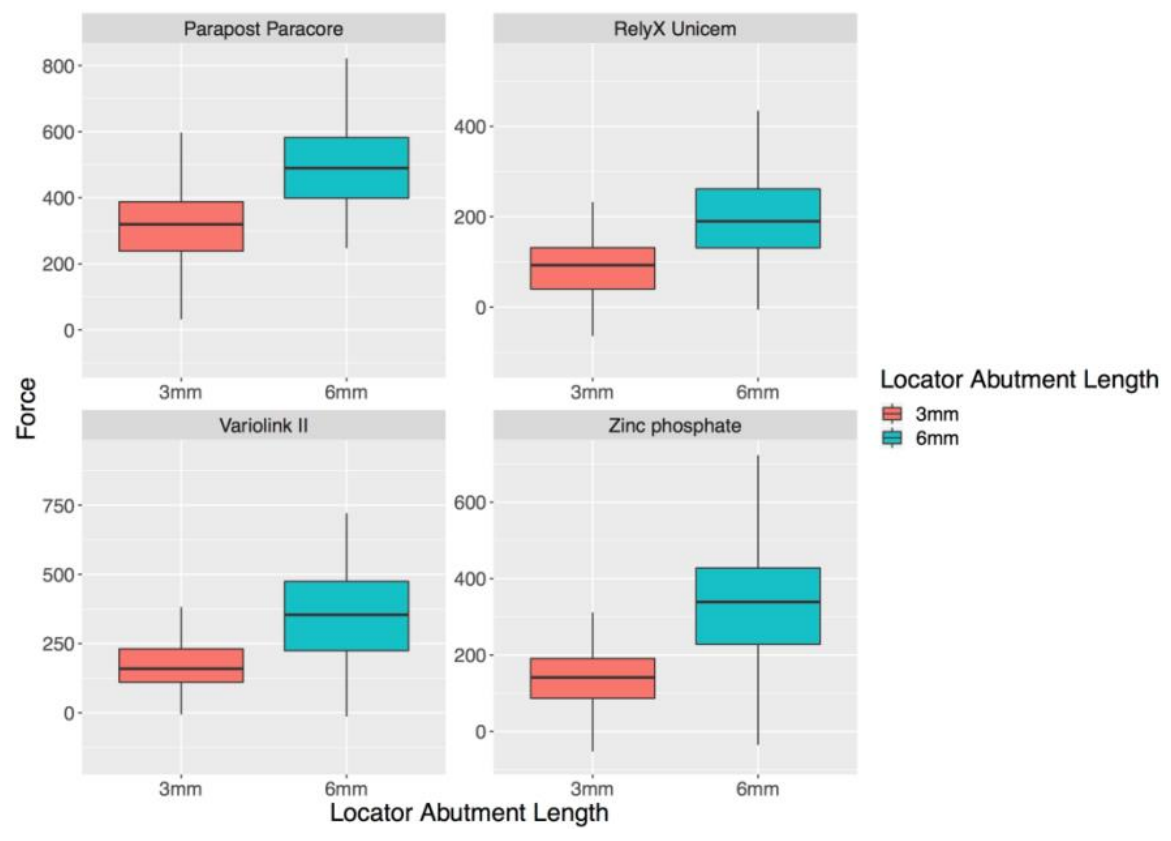




\begin{tabular}{|c|c|c|c|}
\hline Material & Brand & Manufacturer & Chemical Composition \\
\hline $\begin{array}{l}\text { Dual-polymerized } \\
\text { glass-reinforced } \\
\text { resin composite }\end{array}$ & $\begin{array}{l}\text { ParaPost } \\
\text { Paracore }\end{array}$ & $\begin{array}{l}\text { Parapost, Coltene } \\
\text { Whaledent, } \\
\text { Altstätten, } \\
\text { Switzerland }\end{array}$ & $\begin{array}{l}\text { Bis-GMA, UDMA, } \\
\text { Trimethylolpropantrimethacrylate, } \\
\text { TEGDMA, Fluoride, Barium glass, } \\
\text { Amorphous silica }\end{array}$ \\
\hline $\begin{array}{l}\text { Dual-polymerized } \\
\text { resin composite }\end{array}$ & Variolink II & $\begin{array}{l}\text { Ivoclar Vivadent, } \\
\text { Schaan, } \\
\text { Liechtenstein }\end{array}$ & $\begin{array}{l}\text { Paste A: Bis-GMA, UDMA, TEGDMA, barium } \\
\text { glass, ytterbium trifluoride, initiator, } \\
\text { stabilizer } \\
\text { Paste B: Bis-GMA, UDMA, TEGDMA, barium } \\
\text { glass, ytterbium trifluoride, Ba-Al- } \\
\text { fluorosilicate glass, and spheroid mixed } \\
\text { oxide, initiator, stabilizers }\end{array}$ \\
\hline $\begin{array}{l}\text { Dual-polymerized, } \\
\text { self adhesive resin } \\
\text { composite }\end{array}$ & RelyX Unicem & $\begin{array}{l}\text { 3M-ESPE, St. } \\
\text { Paul, MN }\end{array}$ & $\begin{array}{l}\text { Powder: glass powder, silica, calcium } \\
\text { hydroxide, substitute pyrimidine, peroxy } \\
\text { compound, pigment, initiator } \\
\text { Liquid: methacrylated phosphoric ester, } \\
\text { dimethacrylate, stabilizer, initiator }\end{array}$ \\
\hline Zinc phosphate & Kleio & $\begin{array}{l}\text { Lascod SpA, } \\
\text { Florence, Italy }\end{array}$ & $\begin{array}{l}\text { Powder: Zinc oxide } \\
\text { Liquid: Buffered solution of phosphoric } \\
\text { acid }\end{array}$ \\
\hline
\end{tabular}

Table 1. Types, brands, manufacturers and chemical compositions of luting cements used in this study.

Bis-GMA: Bisphenol-A-diglycidylmethacrylate; UDMA: Urethane dimethacrylate; TEGDMA: triethylene glycol dimethacrylate. 
Table 2. Summary of 2-way ANOVA and Tukey`s tests of main factors (cement materials and different lengths) and their interaction for retention of locator abutments. $D f$, degrees of freedom.

\begin{tabular}{llcccrr}
\multicolumn{1}{c}{ Source } & $\begin{array}{c}\text { Sum of } \\
\text { squares }\end{array}$ & $\boldsymbol{d f}$ & $\begin{array}{c}\text { Mean } \\
\text { square }\end{array}$ & F & $\boldsymbol{P}$ \\
Cement & 750548.371 & 3 & 250182.790 & 17.488 & $<.0001$ \\
Length & 581220.363 & 1 & 581220.363 & 40.627 & $<.0001$ \\
Cement x & 31497.429 & 3 & 10499.143 & 0.734 & $>.05$ \\
Length & & & & & \\
Error & 1030057.150 & 72 & 14306.349 & & \\
Total & 7802103.861 & 80 & & &
\end{tabular}


Table 3. Mean force and standard deviations (SD) for retention of locator abutment in Newtons (N). Similar uppercase letters in each row and similar lowercase letters in each column indicate statistically no significant difference $(\alpha=.05)$.

\begin{tabular}{lcc}
\hline Cement type & \multicolumn{2}{c}{ Locator abutment length } \\
\cline { 2 - 3 } & $\mathbf{3} \mathbf{~ m m}$ & $\mathbf{6 ~ m m}$ \\
& Mean \pm SD & Mean \pm SD \\
Parapost Paracore & $314 \pm 116 \mathrm{Aa}$ & $510 \pm 107_{\mathrm{Ba}}$ \\
Variolink II & $156 \pm 95 \mathrm{Ab}$ & $353 \pm 187_{\mathrm{Bab}}$ \\
RelyX Unicem & $94 \pm 62 \mathrm{Ab}$ & $196 \pm 90 \mathrm{Bb}$ \\
Zinc phosphate & $134 \pm 93 \mathrm{Ab}$ & $321 \pm 155_{\mathrm{Bb}}$ \\
\hline
\end{tabular}

